\title{
Review
}

\section{On resistance: A philosophy of defiance}

\author{
Howard Caygill \\ Bloomsbury, London, 2013, 264pp., ISBN: 978-1472526564
}

Contemporary Political Theory (2016) 15, e36-e39. doi:10.1057/cpt.2015.16;

published online 19 May 2015

Howard Caygill begins On Resistance with an interesting double move. First, he points to the problem of forming concepts about practices of resistance, rooted, as they are, in particular actions, specific tactical statements and singular sociohistorical situations. In this respect, resistance, as a historically specific and continually evolving series of practices in the actual, is immediately 'resistant to philosophical analysis' and a 'philosophy of resistance has itself to resist the pressure of concept formation' (p. 6). So how does one move from considering particular practices of resistance to a more general philosophical reflection on their significance? And indeed why should we be motivated to do so? For Caygill it is important to understand that, although practices of resistance are lived out and constantly reinvented in the actuality of specific historical situations, this history nonetheless demands philosophical reflection. There is, and this is his second move, a philosophical responsibility that we need to exercise in uncovering and highlighting what the history of resistances has to offer the contemporary philosophical and political imagination. To that end, Caygill raises the possibility of 'organizing the historical archive of resistances and so making the experience of resistance theoretically available to future calls and occasions for it' (p. 7). Indeed, he does more than raise this as a possibility. He consistently makes good on the suggestion, across this quite brilliant book, as he goes about assembling an archive of political resistance made up from a very interesting and diverse cast of characters.

The voices selected, raised and recorded in Caygill's archive of resistance are many and varied. Whether discussing Marx, Lenin, Luxemburg, Gramsci, Benjamin, Mao, Gandhi, Fanon, the Zapatistas, the Black Panthers, the women of Greenham Common, The Invisible Committee, Occupy, The Arab Spring, Pasolini, Genet, Kafka, Arendt, Schmitt, Freud, Levinas, Foucault, Debord, Vaneigem or, the ever present and centrally important, Carl Von Clausewitz, Caygill consistently shows his capacity for intellectual and political generosity and, consequently, the reader is warmly invited to also participate in the plundering of the archive of resistance. Whether engaging with Vaneigem's Revolution of Everyday Life, Clausewitz's On

(C) 2016 Macmillan Publishers Ltd. 1470-8914 Contemporary Political Theory Vol. 15, 1, e36-e39 
War, Brooke's The Revolution will be Digitised, Huey P Newton's Revolutionary Suicide, Pasolini's Salo or 120 Days of Sodom, or Kafka's parable of the Law from The Trial, what we see, time and again, is Caygill's ability as a reader come through as he dramatizes experiences, practices and concepts of resistance in a way that breathes new life into them for a contemporary audience. Rather than an archivist of resistance, perhaps it is better to think of Caygill as a dramatist, as directing or staging a thoroughly engaging drama that captivates us, implicates us, draws us in and provokes us.

Given the ambition of the text, and given his desire to draw on such a multiplicity of source material, we may wonder whether, and how, Caygill manages to maintain his own authorial voice among the throng of all the other voices that pitch in here and there across the text. He does indeed maintain a distinct authorial voice, and he maintains it by way of an interesting provocation. Two related points are worth making here in order to tease out this suggestion. The first relates to the central significance of Clausewitz, undoubtedly the key character in Caygill's drama. The second relates to the normative complications and provocations implied by Caygill's notion of resistance. I will take each point in turn. On Resistance begins with, and never tires of returning to, the Clausewitzian idea of resistance as a form of energy that can energize, the conversion of resistant energy into life, affirmation, maybe even social and political change. The following passage on Vaneigem's Revolution of Everyday Life is good example of how Clausewitzian intuitions pervade the text and give a particular cogency and focus to Caygill's specific readings of the figures we encounter through him. Caygill writes:

Vaneigem sees love and generosity as the bases for a new resistance, but one that does not engage power on its terrain of enmity and opposed force but instead constructs its own new terrain. The terrain is not that of the Hegelian dialectic but rather a Clausewitzian duel between the death of power and the life of love, identifying the conflict in the Freudian opposition between the death drive and the pleasure principle - power/stasis and love/creativity. The first of ... two parts, 'Power's Perspective', presents an analysis of everyday life from the standpoint of power and death ... Part 2, on the contrary, attempts a 'reversal of perspective' [and] a break with ... power ... With this we arrive at resistance and the conclusive challenge; 'You won't fuck with us any longer' ... (p. 180)

Caygill neatly sums up the narrative thrust of Vaneigem's Revolution of Everyday Life, but does not dilute the provocation; indeed he restages the provocation in Clausewitzian terms as a duel between the death of power and the life of love. This brings us to the second point concerning normative complications. Put simply, On Resistance builds on Clausewitz in implicitly and explicitly resisting the suggestion that practices of resistance can somehow be easily predetermined in accordance with particular, or readily identifiable, normative values. This concern about normatively 
prescribing or predetermining practices of resistance crystallizes around Caygill's suggestion that they have an 'ambivalent and ambiguous' relation to the 'modern adventure of freedom' (p. 208). In other words, practices of resistance can never simply be normatively/morally justified or indeed critiqued in light of a modern conception of freedom or autonomy. The resistant mode of subjectivity and action is not morally and politically defined by the exercise of freedom or autonomy in the Rousseauian or Kantian sense, for Caygill, but by the need to operate in accordance with political actuality and survival. This, again broadly Clausewitzian intuition, is put to very good use in Caygill's dramatization of Kafka's parable of the Law at the end of the book (see pp. 209-211). Yet, Caygill seems to make other kinds of normative/moral noises at different points in the text. Consider the following example:

A surprising feature of resistant subjectivity is its mobilization of the theory of the traditional cardinal virtues of justice, courage/fortitude and prudence in the understanding of resistance. Resistance is motivated above all by a desire for justice, its acts are performed by subjectivities possessed of extreme courage and fortitude and its practice guided by prudence, all three contributing to the deliberate preservation and enhancement of the capacity to resist. (p. 12)

This is a direct challenge to our contemporary political sensibility as Caygill speaks the more traditional language of virtues rather than the modern language of freedom and autonomy. Immediately, we could find ourselves asking: isn't it necessary to think freedom and justice together, where the former is precisely the autonomy of self-legislation or popular self-determination that inevitably tends toward the latter, the just and democratic reflection of the collective will? Such a question, so seemingly obvious and urgent, precisely brings into focus the singularity and provocation of the authorial voice that emerges in On Resistance. As I have been implying, what is crucial here is Caygill's dramatization of his central character Clausewitz, his insistence on political actuality and his challenge, also by way of Levinas, to the (still very much dominant) tendency within modern and contemporary political thought to foreground the normative significance of autonomy. Should we resist the suggestion that practices of resistance can and should be judged according to predetermined normative criteria that foregrounds autonomy? By pushing us in this direction, is Caygill provoking us to consider the broader idea that the normative implications that follow from practices of resistance may always need to be held in suspense, in an ongoing drama that unfolds in the actuality of a political situation that cannot be determined in advance?

The 'great drama of contemporary thought', to borrow a Levinasian phrase used by Caygill (p. 93), needs to be restaged or performed anew, becoming one in which the aporias of autonomy get rehearsed and brought out into the light and life of the everyday. This major work demands our respect and attention not simply because it is a very well ordered and cataloged archive of practices of resistance, but because 
the archive, in Caygill's hands, always seems to have the potential to come alive as a dramatic script or as a series of stage directions and urgings to explore the potential efficacy of revitalising and dramatizing anew the premodern political virtues of justice, courage, fortitude and prudence. Caygill offers us a premodern political grammar that is brought to life and made appropriate to our contemporary situation, something we can use here and now, in our everyday political life. This is an illuminating, engaging and richly detailed philosophical meditation on resistance, a book that careful and considerate readers will find hard to resist.

Robert Porter Ulster University, Londonderry BT52 1SA, Northern Ireland, UK r.porter@ulster.ac.uk 